\title{
Nielegalna imigracja z perspektywy występku umożliwienia lub ułatwienia pobytu na terytorium Rzeczypospolitej Polskiej
}

\author{
MoniKa FiLIPOWSKA-TuthiLL \\ Katedra Prawa \\ Wyższa Szkoła Prawa im. Heleny Chodkowskiej
}

I. Przystąpienie Polski do Unii Europejskiej nie spowodowało masowego napływu cudzoziemców. Niemniej jednak Unia Europejska od początku swego istnienia zmaga się z nielegalną imigracją, która niesie wiele typów zagrożeń bezpieczeństwa państwa, takich jak np. terroryzm, przestępczość gospodarcza, przestępczość zorganizowana, zjawiska niepożądane, przenoszenie konfliktów rozgrywających się w krajach pochodzenia imigrantów na terytoria państwa przyjmujących, obciążenia budżetowe państwa oraz straty gospodarcze wynikające z działalności przestępczej ${ }^{1}$. Dodatkowo, oprócz wymienionych problemów związanych z bezpieczeństwem państw, w ostatnim okresie nielegalna imigracja na terytorium Unii przybrała tak duże rozmiary ${ }^{2}$, że stała się jednym z głównych jej problemów ${ }^{3}$. Obecna bardzo trudna sytuacja w Europie ma bezpośredni wpływ na bezpieczeństwo Polski w dużej mierze z perspektywy swobody przepływu osób i towarów. Warto podkreślić również, iż w ostatnich latach w Polsce przybywa cudzoziemców, którzy mają zamiar pozostania na stałe legalnie bądź niezgodnie z obowiązującymi przepisami prawa.

1 R. Lewandowski, Dokumenty a nielegalna migracja i bezpieczeństwo publiczne, „Człowiek i Dokumenty" 2015, nr 36, http://wwl.pwpw.pl (dostęp: 15.10.2016).

2 Nielegalna imigracja do UE bije rekordy. Granice przekroczyło ponad półtora miliona ludzi, 15.12.2015, http://wyborcza.pl/1,75477,19349705,nielegalna-imigracja-do-ue-bije-rekordygranice-przekroczylo.html (dostęp: 10.10.2016).

3 Nielegalna imigracja na poziomie wszechczasów, http://www.dw.com/pl/ue-nielegalna-imigracja-na-poziomie-wszechczas (dostęp: 10.10.2016). 
Nielegalna imigracja stała się również jednym ze znaczących źródeł dochodu zorganizowanych grup przestępczych, a uzyskiwane z niej środki służą do prowadzenia przestępczej działalności w innych obszarach.

W przypadku gdy ludność napływowa z jakichkolwiek powodów jest zainteresowana uniknięciem środków ograniczających imigrację, stosowanych przez kraj docelowy, może zdecydować się na imigrację nielegalną, którą można zdefiniować jako: „wjazd na teren kraju docelowego lub pozostanie na jego terenie w sposób naruszający prawodawstwo kraju przyjmującego"^4.

Zagadnienia imigracji zawarte są również w przepisach Traktatu o Unii Europejskiej ${ }^{5}$ oraz Traktatu o funkcjonowaniu Unii Europejskiej ${ }^{6}$. Mają one zapewnić swoim obywatelom przestrzeń wolności, bezpieczeństwa i sprawiedliwości bez granic wewnętrznych, w której zagwarantowana jest swoboda przepływu osób, w powiązaniu z właściwymi środkami w odniesieniu do kontroli granic zewnętrznych, azylu, imigracji, jak również zapobiegania i zwalczania przestępczości. Artykuł 3 ust. 2 Traktatu o Unii Europejskiej ustanowił jedną z podstawowych wartości i praw gwarantowanych przez Unię Europejską — swobodny przepływ osób, zapewniony przez stworzenie przestrzeni bez granic wewnętrznych Unii Europejskiej, której bezpieczeństwo zagwarantowane będzie odpowiednimi instrumentami w zakresie azylu, imigracji oraz zapobiegania przestępczości i kontroli granic zewnętrznych.

W art. 79 ust. 1 Traktatu o funkcjonowaniu Unii Europejskiej ustanowiono, że Unia Europejska rozwija wspólną politykę imigracyjną, która ma na celu skuteczne zarządzanie przepływami migracyjnymi, sprawiedliwe traktowanie obywateli państw trzecich przebywających legalnie w państwach członkowskich i zapobieganie oraz wzmocnienie zwalczania nielegalnej imigracji i handlu ludźmi.

W preambule dyrektywy Rady 2002/90/WE z dnia 28 listopada 2002 r., definiującej ułatwienia nielegalnego wjazdu, tranzytu i pobytu ${ }^{7}$, Rada Unii Europejskiej wskazała, że jednym z celów Unii Europejskiej jest stopniowe tworzenie przestrzeni wolności, bezpieczeństwa i sprawiedliwości, co oznacza między innymi, że musi być zwalczana nielegalna imigracja. W konsekwencji powinny być podejmowane środki zwalczania pomocy w nielegalnej imigracji — zarówno w związku z nielegalnym przekraczaniem granicy w ścisłym znaczeniu, jak i w celu zwalczania istniejących sieci wykorzystujących ludzi. W tym celu za-

${ }^{4}$ Ewolucja i ocena funkcjonowania III filaru Unii Europejskiej, red. H. Tender-Właszczuk, Kraków 2009, s. 63.

5 Traktat o Unii Europejskiej z dnia 7 lutego 1999 r., Dz.U.UE.2012 C 83 (wersja skonsolidowana).

6 Traktat o funkcjonowaniu Unii Europejskiej z dnia 26 października 2012 r., Dz.U.UE.C Nr 326 (wersja skonsolidowana).

7 Dyrektywa Rady 2002/90/WE z dnia 28 listopada 2002 r. definiująca ułatwienie nielegalnego wjazdu, tranzytu i pobytu, Dz.U. UE L z 2002 r. Nr 328, poz. 17. 
sadnicze znaczenie ma zbliżenie istniejących przepisów prawa, w szczególności z jednej strony, dokładna definicja danego naruszenia i przypadki włączeń, które są przedmiotem niniejszej dyrektywy, oraz, z drugiej strony, minimalne zasady dotyczące karania, odpowiedzialności osób prawnych i jurysdykcji, które są przedmiotem decyzji ramowej Rady 2002/946/WSiSW z dnia 28 listopada 2002 r. w sprawie wzmocnienia systemu karnego w celu zapobiegania ułatwianiu nielegalnego wjazdu, tranzytu i pobytu ${ }^{8}$. Celem niniejszej dyrektywy jest udostępnienie definicji ułatwiania nielegalnej imigracji i w konsekwencji umożliwienie skuteczniejszego zastosowania decyzji ramowej 2002/946/WSiSW w celu zapobiegania temu przestępstwu. Najważniejszym elementem omawianej dyrektywy jest zawarta w art. 1 ust. 1 definicja nielegalnej imigracji, którą określono jako: umyślne pomaganie osobie niebędącej obywatelem państwa członkowskiego we wjeździe lub tranzycie przez terytorium państwa członkowskiego z naruszeniem przepisów dotyczących wjazdu lub tranzytu cudzoziemców; umyślnie pomaganie, dla korzyści finansowych, osobie niebędącej obywatelem państwa członkowskiego w zamieszkaniu na terytorium państwa członkowskiego z naruszeniem przepisów dotyczących pobytu cudzoziemców.

Kolejnym ważnym aktem prawnym jest dyrektywa Parlamentu Europejskiego I Rady 2008/115/WE z dnia 16 grudnia 2008 r. w sprawie wspólnych norm i procedur stosowanych przez państwa członkowskie w odniesieniu do powrotów nielegalnie przebywających obywateli państw trzecich ${ }^{9}$. W preambule do niniejszej dyrektywy wskazano, że przedmiotowy akt jest realizacją ustaleń Rady Europejskiej co do spójnego podejścia w dziedzinie imigracji i azylu, obejmującego utworzenie wspólnego systemu azylowego, polityki imigracyjnej i zwalczania nielegalnej imigracji oraz opracowania skutecznej polityki wydalania i repatriacji, opartej na wspólnych normach, aby osoby, które mają być wydalone, traktowane były w sposób ludzki oraz z pełnym poszanowaniem ich podstawowych praw i godności ${ }^{10}$.

Imigracja, w tym nielegalna, jest związana nie tylko z terytorium państw członkowskich, lecz także z warunkami przedostania się na nie, tj. przekraczaniem granic zewnętrznych Unii Europejskiej. Pomijając kwestie zmiany zasad i przepisów, obecnie przekraczanie granic zewnętrznych strefy Schengen ${ }^{11}$ oraz związane z tym kwestie wizowe regulują rozporządzenie Parlamentu Europejskiego i rozporządzenie Parlamentu Europejskiego i Rady (WE) nr 810/2009 z dnia

8 Punkty od 1 do 6 preambuły dyrektywy Rady 2002/90/WE.

9 Dz.U. UE L z 2008 348/98.

10 Punkty 1-2 preambuły dyrektywy Parlamentu Europejskiego i Rady 2008/115/WE.

11 Decyzja Rady z dnia 6 grudnia 2007 r. w sprawie pełnego stosowania przepisów dorobku Schengen w Republice Czeskiej, Republice Estońskiej, Republice Łotewskiej, Republice Litewskiej, Republice Węgierskiej, Republice Malty, Rzeczypospolitej Polskiej, Republice Słowenii i Republice Słowacji, Dz.U. L 323 z 2007 r. 
13 lipca 2001 r. (kodeks wizowy) $)^{12}$. Jak wskazano w punkcie 6 preambuły do rozporządzenia nr 2016/399 — kontrola graniczna leży w interesie nie tylko państwa członkowskiego, na którego granicach zewnętrznych jest ona dokonywana, lecz w interesie wszystkich państw członkowskich, które zniosły kontrolę graniczną na granicach wewnętrznych. Ponadto kontrola ta powinna pomagać w zwalczaniu nielegalnej imigracji i handlu ludźmi oraz zapobieganiu wszelkim zagrożeniom bezpieczeństwa wewnętrznego, porządku publicznego, zdrowia publicznego i stosunków międzynarodowych państw członkowskich.

II. Zgodnie ze wskazanymi zasadami relacji prawnych pomiędzy prawodawstwem państw członkowskich a prawodawstwem Unii Europejskiej przyjęcie przez Unię Europejską wymienionych aktów spowodowało, z jednej strony, obowiązek dostosowania prawa w państwach członkowskich do przepisów określonych w wymienionych dyrektywach i decyzjach, a z drugiej strony znacznie ograniczyło swobodę państw członkowskich w regulowaniu między innymi takich zagadnień, jak polityka wizowa, imigracyjna, azylowa oraz przeciwdziałanie ich negatywnym objawom.

Występek umożliwienia lub ułatwienia pobytu wbrew przepisom innym osobom na terytorium Rzeczypospolitej Polskiej jest nietypowym czynem zabronionym, ponieważ do wypełnienia jego znamion muszą wystąpić jednocześnie naruszenia prawa administracyjnego, określającego zasady wjazdu i pobytu w naszym kraju. Z nielegalną migracją ściśle powiązane są czyny zabronione, które w polskim prawie zostały spenalizowane w ustawie z dnia 6 czerwca 1997 r. - Kodeks karny, ustawie z dnia 12 grudnia 2013 r. o cudzoziemcach ${ }^{13}$, ustawie z dnia 13 czerwca 2003 r. o udzielaniu cudzoziemcom ochrony na terytorium Rzeczypospolitej Polskiej ${ }^{14}$. Nabywane doświadczenia oraz uzyskiwana wiedza służb, związana z poznawaniem mechanizmów organizowania przerzutu imigrantów do Polski ukazały, że proceder związany z nielegalną imigracją jest bardzo dobrze rozwinięty i obejmuje zachowania stanowiące kolejne etapy następujące już po przekroczeniu granicy państwa. Ustalono, że po przekroczeniu granicy wobec wielu nielegalnych imigrantów podejmuje się czynności zmierzające do legalizacji ich pobytu. Skutkiem rozpoznania tej zależności i procederu dokonano kryminalizacji takich zachowań, ustanawiając w kodeksie karnym art. 264a. Przepis ten został wprowadzony do porządku prawnego w wyniku przyjęcia przez Polskę decyzji ramowej Rady 2002/946/WSiSW oraz dyrektywy Rady 2002/90/WE ${ }^{15}$.

12 Rozporządzenie Parlamentu Europejskiego i Rady (WE) nr 810/2009 z dnia 13 lipca 2009 r. ustanawiające Wspólny Kodeks Wizowy (kodeks wizowy), Dz.U. UE L 243 z 2009 r.

13 Dz.U. z 2013 r. poz. 1650 ze zm.

14 Dz.U. z 2003 r. Nr 128, poz. 1176 ze zm.

15 K. Laskowska, Przestępczość zwiąana z nielegalna imigracja w kontekście przemian zjawiska i prawa, „Białostockie Studia Prawnicze” 2011, z. 9, s. 255. „Art. 1. Granicą Rzeczypospolitej Polskiej, zwaną dalej »granicą państwową«, jest powierzchnia pionowa przechodząca przez linię graniczną, oddzielająca terytorium państwa polskiego od terytoriów innych państw i od morza 
Został on wprowadzony do polskiego porządku prawnego ustawą o zmianie ustawy - Kodeks karny oraz niektórych innych ustaw z dnia 16 kwietnia 2004 r. ${ }^{16}$

Na przedmiotowy powód art. 264a k.k. wskazuje większość autorów opracowań dotyczących przedmiotowego przestępstwa m.in. R.A. StefańskI ${ }^{17}$, L. Gardocki $^{18}$, M. Królikowski ${ }^{19}$, D. Gruszecka ${ }^{20}$. Odmienne stanowisko przedstawia Z. Ćwiąkalski, który uzasadnia, że przepis art. 264a stanowi reakcję na zwiększenie się atrakcyjności Polski dla imigrantów, ich wzmożony napływ i nielegalny pobyt. Często nie byłoby to możliwe bez zaangażowania się innych osób w jego umożliwienie lub ułatwienie ${ }^{21}$.

Dobrem chronionym przez art. 264a k.k. jest ogólnie pojęty porządek publiczny i bezpieczeństwo państwa, co wskazuje już samo umieszczenie tego przepisu w rozdziale XXII kodeksu karnego pod tytułem „Przestępstwa przeciwko porządkowi publicznemu”. Jednak już cele i zakres tej ochrony są przez nich różnie postrzegane. Z. Ćwiąkalski wskazuje, że przedmiotem ochrony jest bezpieczeństwo wewnętrzne Rzeczypospolitej Polskiej i jej obywateli, związane ze sprawowaniem kontroli nad migracją cudzoziemców w Polsce, przy czym w związku z nielegalnym pobytem tych osób w Polsce może powstać zagrożenie związane z przestępczością międzynarodową i terroryzmem ${ }^{22}$. Według R. Stefańskiego ${ }^{23}$ i E. Pływaczewskiego dobrem chronionym jest bezpieczeństwo państwa oraz zapewnienie porządku publicznego w zakresie wjazdu i pobytu cudzoziemców na terytorium

pełnego. Granica państwowa rozgranicza również przestrzeń powietrzną, wody i wnętrze ziemi. Art. 2. Przebieg granicy państwowej na lądzie oraz rozgraniczenia morskich wód wewnętrznych i morza terytorialnego z państwami sąsiednimi są określone w umowach międzynarodowych, zawartych przez Rzeczpospolitą Polską. Art. 3. Granica państwowa na morzu przebiega w odległości 12 mil morskich od linii podstawowej, określonej w odrębnych przepisach, lub po zewnętrznej granicy red włączonych do morza terytorialnego".

16 Dz.U. z 2004 r. Nr 93, poz. 889.

17 R.A. Stefański, Przestepstwo umożliwienia lub ułatwienia nielegalnego pobytu (art. 264a kk), „Prokuratura i Prawo” 2005, nr 11, s. 7

18 System Prawa Karnego, t. 8, Przestęstwa przeciwko państwu i dobrom zbiorowym, red. L. Gardocki et al., Legalis System Informacji Prawnej, https://sip.legalis.pl/document (dostęp: 10.02.2016), art. 264a.

19 Kodeks karny. Część szczególna, t. 2, Komentarz do artykułów 222-316, red. M. Królikowski, R. Zawłocki, Warszawa 2013, Legalis System Informacji Prawnej, https://sip.legalis.pl/ document (dostęp 25.11.2015), art. 264a.

${ }^{20}$ Kodeks karny. Część szczególna. Komentarz, red. J. Giezek et al., Warszawa 2014, System Informacji Prawnej LEX, http://lex.online.wolterskluwer.pl (dostęp: 11.10.2016), art. 264a.

${ }^{21}$ Kodeks karny. Część szczególna. Komentarz do art. 117-277 kk., red. Z. Ćwiąkalski, A. Zoll, Warszawa 2006, System Informacji Prawnej LEX, http://lex.online.wolterskluwer.pl (dostęp: 25.10.2016), art. 264a.

22 Ibidem.

23 R. Stefański, Kodeks karny. Komentarz, Warszawa 2015, Legalis System Informacji Prawnej, https://sip.legalis.pl/document (dostęp: 18.11.2016), art. 264a. 
$\mathrm{RP}^{24}$. Zdaniem K. Wiaka przedmiotem ochrony jest bezpieczeństwo państwa, zagrożone nielegalnym pobytem cudzoziemców na terytorium RP, a często także charakter prowadzonej przez nich działalności ${ }^{25}$. M. Bojarski wskazuje, że przedmiotem ochrony jest porządek w zakresie organizacji pobytu na terenie Rzeczypospolitej Polskiej ${ }^{26}$. Natomiast D. Gruszecka przekonuje, że dobrem prawnie chronionym pozostaje porządek i bezpieczeństwo publiczne związane ze sprawowaniem kontroli nad migracją cudzoziemców w Polsce ${ }^{27}$.

Strona przedmiotowa czynu polega na umożliwieniu lub ułatwieniu innej osobie pobytu na terytorium Rzeczypospolitej Polskiej wbrew przepisom.

Z punktu widzenia językowej wykładni słowo „umożliwiać” oznacza „,czynić coś możliwym, stwarzać warunki sprzyjające czemuś, przyczyniać się do czegoś na przykład umożliwić naukę, ucieczkę"28.

Czynności sprawcze wynikające z charakteru przestępstwa mogą przybrać bardzo różną postać. Z. Ćwiąkalski wskazuje, że może polegać ona na zapewnieniu mieszkania, ukrywaniu danej osoby, załatwieniu jej nielegalnego meldunku lub dostarczaniu odpowiednich dokumentów, podwiezieniu danej osoby, dostarczeniu odzieży lub środków do życia. Oprócz tego może to być pomoc w zmianie wizerunku, umożliwienie pracy, wprowadzenie w błąd właściwych organów zajmujących się cudzoziemcami, przedstawienie wspomnianej osoby jako swojego bliskiego krewnego ${ }^{29}$. Sprawca może również potwierdzać dane niezgodnie ze stanem faktycznym, samodzielnie lub przez właściwy organ, w celu bezprawnego uzyskania przez inną osobę dokumentu, który umożliwi jej nielegalny pobyt. Należy zgodzić się z M. Kalitowskim, iż zachowanie sprawcy może polegać na jakimkolwiek postępowaniu, które prowadzi do umożliwienia lub ułatwienia innej osobie pobytu na terytorium RP niezgodnie z obowiązującymi przepisami ${ }^{30}$. Warunkiem bezprawnego zachowania sprawcy jest umożliwienie lub ułatwienie pobytu innej osobie na terytorium Rzeczypospolitej Polskiej. Terytorium RP natomiast to obszar, wyznaczony granicą państwową, nad którym RP wykonuje swoje zwierzchnictwo ${ }^{31}$. Oczywiście może pojawiać się wiele wątpliwości w interpretowaniu danych zachowań, jak w przypadku zawieranych małżeństw między

24 A. Wąsek, R. Zawłocki, Kodeks Karny. Częśś szczególna. Komentarz do artykułów 222 316, t. 2, Warszawa 2010, Legalis System Informacji Prawnej, https://sip.legalis.pl/document (dostęp: 15.11.2016), art. 264a.

${ }^{25}$ Kodeks karny. Komentarz, red. A. Grześkowiak, K. Wiak, Warszawa 2015, Legalis System Informacji Prawnej, https://sip.legalis.pl/document (dostęp: 15.02.2016), art. 264a.

26 Przestęstwa..., art. 264a.

27 Kodeks karny..., red. J. Giezek.

28 Stownik języka polskiego PWN, t. III, red. M. Szymczak,Warszawa 1995, s. 557.

${ }^{29}$ Kodeks karny..., red. Z. Ćwiąkalski, A. Zoll.

30 Kodeks karny. Komentarz, red. M. Filar et al., Warszawa 2012, http://lex.online.wolterskluwer.pl (dostęp: 10.11.2016).

31 Kodeks karny..., red. M. Królikowski, R. Zawłocki. 
obywatelem Polski a obcokrajowcem. Stwierdzenie nadużycia i łamania prawa w takim przypadku jest bardzo trudne.

Uwzględniając konstrukcję przyjętą w przepisie odnośnie do umożliwienia lub ułatwienia pobytu innej osobie ${ }^{32}$, do realizacji znamion występku wystarczy podjęcie opisanych w nim zachowań co do jednej osoby. Niewątpliwie liczba osób, którym sprawca ułatwiał lub umożliwiał pobyt, będzie wpływać na ocenę stopnia społecznej szkodliwości jego zachowania. Ponadto inną osobą, o której mowa w przepisie, nie może być obywatel Polski, gdyż ten ma prawo przebywać na terytorium Rzeczypospolitej Polskiej ${ }^{33}$, co gwarantuje art. 52 ust. 4 Konstytucji RP, stanowiący, że obywatela polskiego nie można wydalić z kraju ani zakazać $\mathrm{mu}$ powrotu do $\mathrm{kraju}^{34}$. Zachowanie sprawcze w omawianym przepisie dotyczy zachowania podejmowanego w stosunku do osoby, która przebywa lub ma zamiar przebywać na terytorium RP „wbrew przepisom”, a więc osoby, która chce pozostawać na terytorium Rzeczypospolitej bez tytułu prawnego. Osobą tą może być tylko cudzoziemiec ${ }^{35}$.

Przepis ten nie ma specyficznego dla niego przedmiotu czynności sprawczej. Zgodnie z brzemieniem omawianego przestępstwa sprawcą może być każda osoba, w związku z czym ma ono charakter powszechny. Tak więc sprawcą może być, oprócz obywatela $R P$, również cudzoziemiec, przy czym nie jest istotne, czy przebywa on na terytorium kraju zgodnie z przepisami, czy wbrew im. Istotny jest również fakt potrzeby celu, jakim jest osiągnięcie korzyści majątkowej lub osobistej (zamiar bezpośredni, umyślny).

Cel działania sprawcy, czyli osiągnięcie wymienionych korzyści, powoduje, że występek ten należy do przestępstw kierunkowych. $\mathrm{Z}$ tego też powodu, jak właściwie podaje M. Królikowski, sprawca musi chcieć umożliwić lub ułatwić innej osobie pobyt wbrew przepisom pobytu na terytorium RP, albowiem wymienione zachowania zabronione muszą być przez niego podejmowane w celu osiągnięcia korzyści majątkowej lub osobistej. Jednocześnie dla zrealizowania strony podmiotowej sprawca nie musi mieć pewności co do nielegalnego charakteru pobytu cudzoziemca na terytorium RP, lecz wystarczy, że taką możliwość przewi-

${ }^{32}$ Znamię „inna osoba” nie jest w jakikolwiek sposób określone w przepisie i aby ustalić, kto może być przedmiotem bezpośredniego działania, należy ustalić, jakiej osobie sprawca może umożliwić lub ułatwić pobyt wbrew przepisom na terytorium RP. Jak wskazano - nie będzie tą osobą obywatel Polski.

33 Przepisy regulujące warunki legalnego pobytu cudzoziemców na terytorium RP są przede wszystkim określone w: ustawie z dnia 12 grudnia 2013 r. o cudzoziemcach, ustawie z dnia 14 lipca 2006 r. o wjeździe na terytorium Rzeczypospolitej Polskiej, pobycie oraz wyjeździe z tego terytorium obywateli państw członkowskich Unii Europejskiej i członków ich rodzin, ustawie z dnia 13 czerwca 2003 r. o udzielaniu cudzoziemcom ochrony na terytorium Rzeczypospolitej Polskiej oraz ustawie z dnia 9 listopada $2000 \mathrm{r}$. o repatriacji.

${ }^{34}$ Kodeks karny..., red. M. Królikowski, R. Zawłocki.

35 R.A. Stefański, Przestępstwo..., s. 8. 
duje i na to się godzi ${ }^{36}$. Słusznie wskazuje R. Krajewski, że jest to przestępstwo formalne, ponieważ dla jego bytu nie jest konieczne, aby sprawca osiągnął korzyść majątkową lub osobistą. Wystarczy, że dążył do jej uzyskania ${ }^{37}$.

Warunkiem odpowiedzialności jest umożliwienie lub ułatwienie pobytu cudzoziemcowi wbrew przepisom, a nie na przykład pomoc w załatwieniu dokumentów umożliwiających legalny pobyt. Pomimo, że pomoc taka zostałaby udzielona w celu osiągnięcia korzyści majątkowej lub osobistej, to zachowanie osoby jej udzielającej, nie wbrew przepisom, nie wyczerpałoby znamion przedmiotowego przestępstwa ${ }^{38}$. Korzyść majątkową lub osobistą należy rozumieć zgodnie z jej definicją określoną w art. 115 § 4 k.k., tj. korzyść zarówno dla siebie, jak i dla kogoś innego.

Ustawowe zagrożenie karą za przestępstwo umożliwiania lub ułatwiania pobytu na terytorium Rzeczypospolitej Polskiej wbrew przepisom to pozbawienie wolności od 3 miesięcy do 5 lat. Jest to sankcja stosunkowo surowa, choć na podstawie art. $58 \S 3$ k.k. sąd ma możliwość orzeczenia zamiast kary pozbawienia wolności grzywny lub kary ograniczenia wolności do lat 2, w szczególności jeżeli jednocześnie orzeka środek karny. W przypadku gdy sprawca nie otrzymał korzyści majątkowej, może ubiegać się o nadzwyczajne złagodzenie kary bądź całkowite od niej odstąpienie. Do takiej sytuacji może dojść również w przypadku osiągnięcia korzyści osobistej, której ostateczny wymiar i znaczenie należy do oceny sąd.

Jak słusznie zauważa M. Królikowski - do rzeczywistego zbiegu przestępstw dojdzie, gdy sprawca zajmuje się umożliwianiem lub ułatwianiem nielegalnego pobytu cudzoziemcom na terytorium Rzeczypospolitej Polskiej w ramach swojej działalności w zorganizowanej grupie lub związku mającym na celu popełnienie przestępstwa ${ }^{39}$.

Konieczność kumulatywnej kwalifikacji na podstawie art. 264a § 1 oraz art. $264 \S 3$ może zajść w sytuacji, gdy sprawca zarówno organizuje innym osobom przekroczenie granicy Rzeczypospolitej Polskiej, jak i umożliwia lub ułatwia im nielegalny pobyt na terytorium kraju. Możliwy będzie również właściwy zbieg przepisów między art. 264a a przepisami art. 228 lub 229 k.k. w przypadkach łapownictwa, przepisem art. 231 k.k., gdy funkcjonariusz publiczny przekracza swoje uprawnienia lub nie dopełnia obowiązków i w ten sposób umożliwia lub ułatwia nielegalny pobyt, jak również przepisami typizującymi czyny przeciwko wiarygodności dokumentów (art. 270 i n. k.k.) ${ }^{40}$. Jak zasadnie wskazuje Z. Ćwią-

${ }^{36}$ Kodeks karny..., red. M. Królikowski, R. Zawłocki.

37 R. Krajewski, Przestępstwo umożliwienia lub ułatwienia nielegalnego pobytu na terytorium Rzeczypospolitej Polskiej. Studia z zakresu prawa, administracjii i zadzadzania Uniwersytetu Kazimierza Wielkiego w Bydgoszczy, t. 2, Warszawa 2012, s. 50.

38 Ibidem, s. 52.

39 Kodeks karny..., red. M. Królikowski, R. Zawłocki, art. 264a.

40 Kodeks karny..., red. J. Giezek. 
kalski - w tym przypadku zachodzi kumulatywny zbieg wymienionych przepisów w ten sposób, że sprawca w celu umożliwienia lub ułatwienia nielegalnego pobytu cudzoziemcowi na terytorium RP dopuścił się fałszerstwa dokumentu ${ }^{41}$.

III. Przebywanie cudzoziemców wbrew przepisom na terytorium RP stwarza bardzo szerokie spektrum zagrożeń państwa i obywateli — od administracyjnych, jak nielegalne zatrudnienie, do zorganizowanej przestępczości międzynarodowej i terroryzmu.

Problem nielegalnej imigracji w Polsce w sposób najbardziej kompetentny i zwięzły ukazany jest w Raporcie o stanie bezpieczeństwa w Polsce w 2014 r. ${ }^{42}$ Ministerstwa Spraw Wewnętrznych ${ }^{43}$. Zgodnie z jego treścią to położenie Polski oraz jej członkostwo w strukturach Unii Europejskiej, jak również przynależność do strefy Schengen powodują stałe zainteresowanie naszym krajem wśród obywateli państw trzecich i międzynarodowych grup przestępczych. Obecnie Polska traktowana jest zarówno jako kraj tranzytowy do innych państw Europy Zachodniej oraz Ameryki Północnej, jak i kraj docelowej migracji. Sprzyjają temu m.in. ustabilizowane diaspory oraz różnice w rozwoju gospodarczym, występujące między krajami Unii Europejskiej a pozostającymi poza nimi, w szczególności krajami trzeciego świata. Sytuacja ta powoduje, że nielegalna migracja jest zjawiskiem stale rosnącym, przy ewentualnych zmianach form i metod organizowania oraz źródeł strumieni migracyjnych, uzależnionych od zmian geopolitycznych i pojawiających się na świecie konfliktów zbrojnych. Nie ma możliwości określenia jednego, typowego sposobu działania sprawców. Dodatkową trudność stanowi nadużywanie procedur umożliwiających pobyt na terytorium Polski ${ }^{44}$.

Omawiany występek jest elementem przeciwdziałania ogólnie pojętej nielegalnej imigracji, która w chwili obecnej przybrała nieznane wcześniej rozmiary, stając się jednym z głównych zagrożeń i problemów Unii Europejskiej, a z uwagi na łączące więzi prawno-organizacyjno-gospodarcze odnosi się ona również do naszego kraju.

${ }^{41}$ Kodeks karny..., red. Z. Ćwiąkalski, A. Zoll.

42 Raport o stanie bezpieczeństwa w Polsce w 2014 r., Ministerstwo Spraw Wewnętrznych, http://bip.mswia.gov.pl/bip/raport-o-stanie-bezpie/18405, Raport-o-stanie-bezpieczenstwa.html (dostęp: 26.11.2016).

43 Raport o stanie bezpieczeństwa w Polsce w 2014 roku został przygotowany na podstawie informacji przedstawionych przez służby podległe Ministrowi Spraw Wewnętrznych oraz danych pochodzących z innych instytucji, których zadania obejmują zwalczanie przestępstw i zapewnianie szeroko pojętego bezpieczeństwa. Raport stanowi próbę całościowego przedstawienia stanu bezpieczeństwa w Polsce w roku 2014 i w latach poprzednich, dostosowaną do różnych sposobów gromadzenia danych przez poszczególne organy ścigania i instytucje wymiaru sprawiedliwości. Ibidem, s. 5.

44 Ibidem, s. 101-102. 


\section{Illegal immigration from the perspective of the crime of enabling or facilitating stay on the Polish territory}

\section{Summary}

This article is devoted to the important and very current problem of immigration, from the perspective of European Union and Polish regulations. This paper analyzes the crime of enabling and facilitating the illegal stay on the Polish territory, where the perpetrator acts for personal or financial gain. The subject here is the protection of public safety and order against unauthorized aliens. Illegally staying in the Republic of Poland, foreigners create a broad spectrum of threats to the state and its citizens (from administrative to illegal employment in organized crime and international terrorism).

Keywords: immigration, illegal aliens, criminal law. 